\title{
TIPS DAN TRIK PENGELOLAAN KEUANGAN MELALUI KOPERASI SEKOLAH DI SMK AL-FARUQI KAMPAR
}

\author{
Adriyanti Agustina Putri*, Wira Ramashar, Nadia Fathurahmi Lawita, Zul Azmi, \\ Siti Rodiah, Della Hilia Anriva, Muhammad Ahyaruddin, Agustiawan, \\ Evi Marlina, Isran Bidin \\ Prodi Akuntansi, Fakulatas Ekonomi dan Bisnis UMRI \\ email: adriyantiagustinaputri@umri.ac.id
}

\begin{abstract}
This Training and counseling is also intended to provide education about the importance of school cooperation and good financial planning. This activities are carried out in SMK Al Faruqi at Kubang Raya Street, Desa Tarai Bangun, Kecamatan Tambang, Kabupaten Kampar. According to observation result, it is obtained that the school has not a school cooperation, yet. This training and counseling is attended by all participants who are teachers and students.

The result shows that the participants have high enthusiasm in describing examples and discussion sessions. The school found this activities are helpful because they get information on how to form a cooperation that has been planned before. So, this cooperation can be useful to this school.
\end{abstract}

Keywords: school cooperation, cooporation finance

\section{Abstrak}

Pelatihan dan penyuluhan ini juga dimaksudkan untuk memberikan pemahaman tentang pentingnya koperasi sekolah dan pelatihan dalam mengelola keuangan koperasi dengan baik. Kegiatan ini dilakukan di SMK Al-Faruqi yang terletak di Jalan Kubang Raya Desa Tarai Bangun Kec. Tambang Kab. Kampar. Berdasarkan kunjungan ke sekolah tersebut diperoleh informasi bahwa sekolah belum memiliki koperasi sekolah.

Penyuluhan dan pelatihan diikuti oleh para peserta yang terdiri dari guru dan siswa. Hasilnya menunjukkan adanya antusiasme dalam pelatihan dengan memberikan contoh-contoh praktis dan media diskusi serta sesi tanya jawab pada penyuluhan dan pelatihan tersebut. Dengan adanya kegiatan ini pihak sekolah juga merasa sangat terbantu sehingga mereka memiliki pengetahuan dan pemahaman dalam untuk membentuk sebuah koperasi sekolah yang telah direncanakan sebelumnya, yang nantinya dapat memberikan manfaat bagi pihak sekolah.

Kata kunci: koperasi sekolah, keuangan koperasi

\section{PENDAHULUAN}

Koperasi merupakan organisasi bisnis yang dimiliki dan dioperasikan oleh orang-seorang untuk kepentingan bersama. Koperasi merupakan perekonomian sesuai dengan ciri khas masyarakat kita yaitu gotong-royong. Dengan semangat gotong-royong ini tujuan koperasi akan mudah untuk dicapai. Tujuan utama koperasi adalah untuk mengembangkan kesejahteraan anggota khususnya dan masyarakat pada umumnya. Dimana tujuan koperasi ini selaras dengan cita-cita luhur pendirian bangsa Indonesia yaitu untuk mewujudkan masyarakat adil dan makmur.

Landasan dasar dalam koperasi Indonesia berakar pada UUD 1945 pasal 33 ayat (1) yang berisi cita-cita untuk mengembangkan ekonomi yang berasaskan kekeluargaan. Selanjutnya 
UU Nomor 25 Tahun 1992 memberikan pedoman bagi pemerintah dan masyarakat tentang cara-cara untuk menjalankan koperasi, termasuk koperasi sekolah unincorporated koperasi. Administrator koperasi sekolah dilakukan oleh siswa di bawah bimbingan kepala sekolah dan guru.

Dari hasil kunjungan ke SMK AlFaruqi diperoleh informasi bahwa sekolah tersebut belum memiliki koperasi dan pengelola sekolah sebenarnya telah memiliki keinginan untuk membentuk sebuah koperasi namun belum terbentuk karena keterbatasan dalam tata cara pembentukan serta pengelolaan keuangan koperasi yang baik.

Berdasarkan permasalahan tersebut dosen prodi Akuntansi Fakultas Ekonomi dan Bisnis Universitas Muhammadiyah Riau berminat untuk melakukan pengabdian masyarakat dengan memberikan penyuluhan tentang peran koperasi sekolah dan pelatihan dalam pengelolaan keuangan koperasi sekolah yang nantinya dapat mengembangkan potensi perekonomian di lingkungan sekolah tersebut.

\section{Koperasi}

Koperasi adalah badan hukum yang berdasar atas asas kekeluargaan yang semua anggotanya terdiri dari perorangan atau badan hukum dengan tujuan untuk mensejahterakan anggotanya. Koperasi juga bisa diartikan sebagai badan usaha yang mempunyai anggota yang setiap anggota memiliki tugas dan tanggung jawab masing masing dimana setiap anggota mempunyai hak suara yang sama dalam setiap keputusan yang akan diambil.

Berdirinya koperasi memiliki tujauan utama yaitu untuk memajukan kesejahteraan anggota pada khususnya dan masyarakat pada umumnya serta turut serta membangun tatanan perekonomian nasional dalam rangka mewujudkan masyarakat yang maju, adil dan makmur berlandaskan Pancasila dan Undang undang dasar 45. Selain itu, koperasi memiliki fungsi dan peranan yang tertuang dalam UU No. 25 Tahun 1992 Pasal 5 (Rahardja, 2005:126 ), sebagai berikut :

1. Membangun dan mengembangkan potensi dan kemampuan ekonomi anggota pada khususnya dan masyarakat pada umumnya untuk meningkatkan kesejahtraan ekonomi dan sosialnya.

2. Berperan serta secara aktif dalam upaya mempertinggi kualitas kehidupan manusia dan masyarakat.

3. Memperkokoh perekonomian rakyat sebagai dasar kekuatan dan ketahanan perekonomian nasional dengan koperasi sebagai sokogurunya.

4. Berusaha untuk mewujudkan dan mengembangkan perekonomian nasional yang merupakan usaha bersama berdasarkan azas kekeluargaan dan demokrasi ekonomi.

Sedangkan prinsip koperasi didalam Undang-Undang Nomor 25 tahun 1992 Pasal 5 adalah sebagai berikut :

a. Keanggotaan bersifat sukarela dan terbuka;

b. Pengelolaan dilakukan secara demokratis;

c. Pembagian sisa hasil usaha dilakukan secara adil sebanding dengan besarnya jasa usaha masing-masing anggota;

d. Pemberian balas jasa yang terbatas terhadap modal;

e. Kemandirian;

Dalam mengembangkan koperasi, maka koperasi melaksanakan pula prinsip koperasi sebagai berikut :

a. Pendidikan perkoperasian

b. Kerja sama antar koperasi 


\section{Koperasi Sekolah}

Koperasi sekolah merupakan koperasi yang didirikan di sekolah yang anggotanya terdiri dari siswa/siswi sekolah. Koperasi sekolah dapat didirikan di berbagai jenjang pendidikan, seperti koperasi SD, SMA, SMA dan lembaga pendidikan lainnya. Koperasi sekolah selain sebagai media pembelajaran, juga dapat memberikan sumbangsih dalam menambah penghasilan sekolah dan membantu membangun perekonomian masyarakat.

Koperasi sekolah sangat berperan dalam menumbuhkan jiwa setia kawan, saling menghargai, kesamaan derajat dan gotong royong antar sesamanya dan menumbuhkan serta mengasah demokrasi, kreativitas, kemampuan dan pengetahuan bagi para siswa melalui pengelolaan usaha koperasi sekolah. Berbagai jenis usaha yang dapat dilakukan melalui koperasi sekolah antara lain seperti usaha pertokoan, usaha kafetaria (kantin), pengadaan alatalat sekolah, pengadaan seragam, pengadaan alat-alat laboratorium serta kegiatan simpan pinjam. Dengan keberadaan koperasi sekolah ini dapat mengembangkan pendidikan karakter dan kewirausahaan.

Priambodo (2006) menyatakan bahwa koperasi sekolah memiliki nilai dan potensi yang strategis dan menjadi faktor utama untuk mengatasi permasalahan perluasan kesempataan kerja dan pertumbuhan wirausaha baru. Melalui kegiatan koperasi sekolah, para lulusan yang tidak melanjutkan sekolah, dipersiapkan untuk memiliki alternatif menjadi pencari kerja atau menjadi wirausaha. Alternatif tersebut dimungkinkan karena koperasi sekolah sebagai badan usaha memberikan manfaat ganda terhadap para siswa sebagai anggota koperasi sekolah yaitu siswa dapat secara langsung mengenal, melihat, dan mempraktekkan teori dalam kehidupan nyata di koperasi sekolah. Selain itu, koperasi sekolah digunakan sebagai wahana pembelajaran berusaha, sehingga siswa memperoleh pengetahuan dan keterampilan berusaha yang bermanfaat untuk menumbuhkaan jiwa kewirausahaan yang berakibat tumbuhnya keberanian untuk berusaha secara mandiri sehingga mampu meciptakan lapangan kerja dan mengurangi pengangguran dan kemiskinan.

\section{Keuangan Koperasi}

Mengingat karakteristik badan usaha koperasi berbeda dengan badan usaha lainnya, maka sistem manajemen dan pengelolaan keuangan di dalam organisasi koperasi pun mempunyai karakteristik tertentu. Oleh karena itu, untuk dapat memahami karakteristik dari sistem pembukuan dan keuangan dalam badan usaha koperasi, maka harus terlebih dulu dapat memahami dengan baik mengenai karakteristik badan usaha koperasi. Dengan memahami karakteristik koperasi dan prinsipprinsip koperasi, maka akan dapat pula dipahami prinsip-prinsip keuangan yang khusus untuk sebuah badan usaha koperasi seperti yang tercantum dalam standar akuntansi yang khusus dibuat oleh Ikatan Akuntan Indonesia tersebut, antara lain sebagai berikut:

\section{Sisa Hasil Usaha (SHU)}

SHU tahun berjalan dapat dibagikan kepada para anggota koperasi sesuai dengan ketentuan yang berlaku dalam Anggaran Dasar dan Anggaran Rumah Tangga koperasi. Dengan pengaturan dan ketentuan yang jelas ini, maka setiap bagian dari SHU yang tidak menjadi hak koperasi diakui sebagai kewajiban. Apabila jenis dan jumlah pembagiannya belum diatur secara jelas, maka SHU tersebut dicatat sebagai SHU belum dibagi dan harus dijelaskan dalam catatan atas laporan keuangan. 


\section{Kewajiban}

1. Simpanan anggota yang tidak termasuk dalam kualifikasi sebagai ekuitas, diakui sebagai kewajiban jangka pendek atau jangka panjang sesuai dengan tanggal jatuh temponya dan dicatat sebesar nilai nominalnya

2. Simpanan anggota yang dikualifikasikan sebagai ekuitas adalah sejumlah tertentu dalam nilai uang yang diserahkan oleh anggota pada koperasi atas kehendak sendiri sebagai simpanan dan dapat diambil sewaktu-waktu sesuai perjanjian. Simpanan ini tidak menanggung risiko kerugian dan sifatnya sementara karenanya diakui sebagai kewajiban koperasi.

\section{Aktiva}

Aktiva atau harta koperasi yang diperoleh dari sumbangan yang terikat penggunaannya dan tidak dapat dijual untuk menutup kerugian koperasi diakui sebagai aktiva lain-lain. Sifat keterikatan penggunaan tersebut dijelaskan dalam catatan atas laporan keuangan.

Rapat anggota koperasi dapat menetapkan pengumpulan dana tertentu dari anggota yang digunakan untuk tujuan khusus sesuai kepentingan anggota. Dana tersebut merupakan milik anggota yang pengelolaannya dikuasakan kepada koperasi, misalnya dana untuk melakukan pemeliharaan jalan dan peremajaan kebun pada koperasi perekebunan kelapa sawit. Dana tersebut diakui sebagai aktiva koperasi. Namun sebagai pengelola, koperasi harus membuat pertanggungjawaban tersendiri dan keberadaan dana tersebut harus dijelaskan dalam catatan laporan keuangan.

\section{Transaksi Usaha Koperasi}

1. Pendapatan koperasi yang timbul dari transaksi dengan anggota diakui sebesar partisipasi bruto. Partisipasi bruto pada dasarnya adalah penjualan barang atau jasa kepada anggota. Dalam kegiatan pengadaan barang dan jasa untuk anggota, partisipasi bruto dapat dihitung dari harga pelayanan yang diterima atau dibayar oleh anggota yang mencakup beban pokok dan partisipasi neto. Dalam kegiatan pemasaran hasil produksi anggota, partisipasi bruto dapat dihitung dari beban jual hasil produksi anggota kepada non-anggota maupun kepada anggota;

2. Pendapatan koperasi yang berasal dari transaksi dengan nonanggota diakui sebagai pendapatan (penjualan kepada umum) dan dilaporkan secara terpisah dari pendapatan yang berasal dari anggota dalam laporan perhitungan hasil usaha sebesar nilai transaksi. Selisih antara pendapatan dan beban pokok transaksi dengan non-anggota diakui sebagai laba atau rugi kotor dengan non-anggota. Pemisahan pendapatan dari nonanggota dan anggota dilakukan guna mencerminkan bahwa usaha koperasi lebih mementingkan transaksi atau pelayanan kepada anggotanya daripada non-anggota;

3. Beban usaha dan beban-beban perkoperasian harus disajikan terpisah dalam laporan perhitungan hasil usaha. Dalam meningkatkan kesejahteraan anggota, koperasi tidak hanya berfungsi menjalankan usaha-usaha bisnis yang memberikan manfaat atau keuntungan ekonomi kepada anggotanya, tetapi dapat juga menjalankan fungsi lain untuk meningkatkan kemampuan ekonomi dari yang bukan anggota, baik secara khusus maupun secara nasional. Kegiatan ini tidak dilakukan oleh badan usaha lain. Beban-beban yang 
dikeluarkan untuk kegiatan ini disebut dengan beban perkoperasian. Termasuk dalam beban ini antara lain adalah beban pelatihan anggota, beban pengembangan usaha anggota dan beban iuran untuk gerakan koperasi nasional.

\section{Tujuan Kegiatan dan rencana pemecahan masalah}

Koperasi sekolah sangat berperan dalam pembelajaran bagi para siswa/siswi untuk menumbuhkan jiwa setia kawan, saling menghargai, kesamaan derajat dan gotong royong antar sesamanya serta dapat memberikan sumbangsih dalam menambah penghasilan sekolah dan membantu membangun perekonomian masyarakat di lingkungan sekolah. Berdasarkan informasi yang diperoleh dari hasil kunjungan ke SMK Al-Faruq bahwa sekolah tersebut baru berdiri selama 2 (dua) tahun dan pihak sekolah sudah memiliki keinginan untuk membentuk sebuah koperasi sekolah namun masih terdapat keterbasan dalam pengetahuan tentang langkah dan persyaratan untuk pembentukan serta kurangnya pemahaman dan pengetahuan dalam mengelola keuangan koperasi terutama dalam hal penyusunan laporan keuangan yang baik.

Dari hasil kunjungan ke lapangan dan penjelasan di atas dapat kami ringkas permasalah mitra yang terjadi terkait dengan koperasi sekolah adalah sebagai berikut:

1. Kurangnya pemahaman dan pengetahuan dari pihak sekolah tentang langkah dan syarat dalam pembentukan koperasi sekolah.

2. Kurangnya pengetahuan tentang pengelolaan keuangan koperasi yang baik terutama dalam pembuatan dalam laporan keuangan.

Proposal pengabdian ini kemudian bertujuan untuk memberikan pemahaman kepada pihak sekolah tentang tips dan trik dalam pengelolaan keuangan koperasi sekolah agar dapat meningkatkan potensi perekonomian masyarakat di lingkungan sekolah.

Kegiatan pengabdian ini bertujuan untuk: (1) memberikan pemahaman akan peran penting dan fungsi koperasi sekolah, (2) memberikan pengetahuan tentang langkah-langkah dan persyaratan dalam pembentukan koperasi sekolah, dan (3) memberikan pelatihan dan pengetahuan dalam pengelolaan keuangan koperasi.

Untuk pemecahan masalah tersebut maka solusi yang ditawarkan adalah melalui program Ipteks bagi masyarakat dengan kegiatan workshop dan pelatihan kepada pihak sekolah yang terdiri dari pengelola, guru, pegawai dan siswa/siswi tentang langkah pembentukan koperasi sekolah dan tips dan trik pengelolaan keuangan koperasi yang baik.

\section{METODE}

Merujuk pada hasil observasi lapangan dan diskusi kepada beberapa peserta tersebut, masih terdapat beberapa permasalahan menyangkut pengelolaan keuangan koperasi, perlunya peningkatan pemahaman bagaimana mengelola keuangan koperasi, adanya perbedaan antara pengelolaan keuangan perusahaan dengan koperasi. Materi yang diberikan dalam pengabdian ini adalah terkait dengan tips dan trik pengelolaan keuangan dengan contoh-contoh untuk meningkatkan pemahaman tentang keuangan koperasi.

Kegiatan pengabdian masyarakat ini dilakukan oleh Dosen Program Studi Akuntansi Fakultas Ekonomi dan Bisnis. Adapun peran mitra adalah memfasilitasi informasi yang cukup dan menyediakan data-data yang mendukung terkait dengan permasalahan riil yang terjadi pada 
kehidupan sehari-hari para guru di sekolah SMK.

Kegiatan pengabdian masyarakat tentang tips dan trik pengelolaan keuangan koperasi yang dilakukan di SMK Al-Faruqi Jl. Kubang Raya Kec. Tarai Bangun Kab. Kampar pada hari Senin tanggal 17 September 2018.

Objek yang menjadi sasaran dari kegiatan pengabdian ini adalah para guru sekolah, pegawai siswa sekolah di SMK Al-Faruqi Jl. Kubang Raya Kecamatan Tarai Bangun Kab. Kampar.

Pengabdian ini dilakukan dengan memberikan penyuluhan dan pelatihan kepada guru dan siswa sekolah. Adapun langkah-langkah yang dilakukan yaitu: (1) tahap meningkatkan pengetahuan individu mengenai koperasi, (2) pada tahap implementasi, setiap individu dibimbing untuk pengelolaan keuangan koperasi.

\section{HASIL DAN PEMBAHASAN}

Aktivitas pengabdian masyarakat ini dimulai dengan persiapan pelaksaan kegiatan, yaitu persiapan tim dengan melakukan rapat koordinasi, pembuatan surat menyurat, dan kegiatan pelatihan dan penyuluhan bagi masyarakat sekolah.

Pada tahap selanjutnya adalah persiapan kelengkapan kegiatan yang meliputi hal-hal sebagai berikut: (a). Mempersiapkan tempat pelaksanaan pelatihan dan penyuluhan, yaitu ruang kelas sekolah yang di sediakan pihak Sekolah. (b). Mempersipkan media presentasi, yaitu slide presentasi dan Infocus/LCD. (c). Pembuatan modul yang akan digunakan dalam workshop dan pelatihan. Modul tersebut dibuat oleh pemateri dengan cakupan berupa materi-materi yang akan diberikan dalam pelatihan. Modul tersebut dibuat dalam bentuk tutorial, teori dan contoh format kertas kerja.

Dalam kegiatan pelatihan tersebut, pemateri menjelaskan tentang tips dan trik pengelolaan koperasi. Aktivitas pendampingan telah dimulai pada tahap ini. Peserta diberikan pendampingan langsung untuk pengelolaan keuangan koperasi.

Workshop dan pelatihan diberikan selama lebih kurang 4 jam dan kemudian dilanjutkan dengan diskusi antara peserta dengan pemateri. Pada sesi diskusi, para peserta terlihat sangat antusias dengan menyampaikan pertanyaan-pertanyaan terkait dengan permasahan yang selama ini mereka hadapi di praktiknya. Banyak peserta yang menyampaikan saran kepada panitia agar kegiatan seperti terus dilakukan dalam rangka untuk meningkatkan pemahaman pengelolaan koperasi. Pada akhir kegiatan, para peserta dan panitia berfoto bersama untuk mengabadikan kegiatan yang dilakukan serta diakhiri dengan makan bersama.

\section{KESIMPULAN}

Kesimpulan dari kegiatan pengabdian masyarakat bagi masyarakat sekolah SMK Al-Faruqi Kecamatan Tarai Bangun Kabupaten Kampar untuk tips dan trik pengelolaan keuangan koperasi adalah sebagai berikut: (a) peserta pelatihan sangat antusias ketika mengikuti pelatihan dan penyuluhan. Para peserta dapat melihat manfaat pelatihan ini, yakni menambah pengetahuan pada bidang koperasi. (b). Berdasarkan sharing yang dilaksanakan pada saat diskusi, tidak ada kesan buruk dari peserta selama pelaksanaan workshop, baik dari segi sarana dan prasarana maupun penyampaian materi, hanya saja perlu dibuat dalam skala yang lebih luas.

Pengabdian selanjutnya tetap diarahkan pada sharing masalah koperasi dan pengembangan pengelolaan keuangan koperasi serta pendampingan baik dari segi aspek manajemen, kelembagaan dan keuangan. 
ISSN : 2550-0198

Pengabdian selanjutnya agar

memperluas tempat kegiatan

pengabdian disarankan menyasar

daerah-daerah disekitar sekolah.

\section{DAFTAR PUSTAKA}

[1] Hadikusuma, Sutantya Rahardja. 2005. Hukum Koperasi Indonesia. Jakarta : PT. Rajagrafindo Persada.

[2] Priambodo. (2006). Koperasi Sekolah: Titik Masuk Menguasai“Lingkaran Setan" Pengangguran dan Kewirausahaan. Jurnal Infokop. No.28 Tahun XXII. 2006 Jakarta: Dekopin.

[3] Undang-undang Nomor 25 Tahun 1992 Tentang Perkoperasian 